\title{
Forecasting Production Trafo to Get SDOH Using Seasonal ARIMA Method in PT. XYZ
}

\section{Peramalan Produksi Trafo untuk Mendapatkan SDOH dengan Menggunakan Metode Seasional ARIMA di PT. XYZ}

\author{
Muhammad Dio Dwi Septian $^{1}$, Tedjo Sukmono ${ }^{2}$ \\ ${ }^{1}$ Program Studi Teknik Industri, Universitas Muhammadiyah Sidoarjo. Indonesia \\ [diodwi09@gmail.com¹,thedjoss@gmail.com²]
}

\begin{abstract}
In the production process at PT. XYZ has a fluctuating data pattern and contains seasonality. This resulted in a reduction in the company's operational efficiency and difficulty in preparing supplies to meet uncertain demand. The method according to the demand pattern at PT. XYZ in this transformer product is the SARIMA method. The results of forecasting on transformer production at PT.XYZ gets the SARIMA $(1,0,1)(1,1,1)$ model with influenced by the results observed at 13 weeks and errors at 14 weeks ago. The results of this forecast are used in determining the safety stock in 2021 with regard to SDOH. The SDOH planning in January 2021 will run out in 30 days with a stock plan of 838 units LV Busing so that a company policy needed to increase or decrease the stock plan if SDOH is below or above 30-35 days.
\end{abstract}

Keywords : Forecasting, SARIMA, Inventory, Stock Day on Hand

\begin{abstract}
Abstrak- Pada proses produksi di PT. XYZ ini memiliki pola data yang fluktuatif serta mengandung musiman. Hal tersebut mengakibatkan berkurangnya efisiensi operasional perusahaan serta mengalami kesulitan dalam menyiapkan persediaan untuk memenuhi permintaan yang tidak menentu. Metode yang sesuai dengan pola permintaan di PT. XYZ pada produk trafo ini yaitu metode SARIMA. Hasil dari peramalan pada produksi trafo di PT. XYZ ini mendapatkan model SARIMA $(1,0,1)(1,1,1)$ dengan dipengaruhi oleh hasil pengamatan pada 13 minggu dan kesalahan pada 14 minggu yang lalu. Hasil peramalan tersebut digunakan dalam menentukan safety stock pada tahun 2021 dengan memperhatikan SDOH. Pada perencanaan SDOH pada bulan Januari 2021 akan habis dalam 30 hari dengan stock plan sebesar 838 unit LV Busing sehingga diperlukan kebijakan perusahaan untuk menambah atau mengurangi stock plan jika SDOH dibawah atau diatas 30-35 hari..
\end{abstract}

Kata kunci : Peramalan, SARIMA, Persediaan, Stock Day On Hand

\section{Pendahuluan}

PT. XYZ merupakan perusahaan manufaktur yang bergerak dibidang produksi trafo yang dimana memiliki pola permintaannya bersifat fluktuatif. Hal ini terjadi karena adanya perusahaan kompetitor yang sejenis yang bersaing melalui lelang atau tender proyek, adanya perubahan kondisi perekonomian serta masih banyak lagi faktor yang mempengaruhi. Dengan adanya permintaan yang fluktuatif mengakibatkan adanya sisa stock yang dimana menurut data yang terkumpul sisa stock tersebut rata-rata lima hingga sepuluh trafo. Dengan terjadinya permasalahan yang timbul maka dapat menurunkan tingkat efisiensi operasional perusahaan yang dimana akan membuat kondisi finansial perusahaan tidak sehat.

Maka dari itu perlu dilakukan pembaharuan pengaturan terhadap proses produksi yang ada sehingga nantinya dapat memenuhi pola permintaan yang masuk secara tiba-tiba. Adanya pembaharuan pengaturan baru juga supaya meningkatkan nilai profitabilitas perusahaan. Adapun pola permintaan yang fluktuatif tersebut digambarkan pada gambar berikut. 


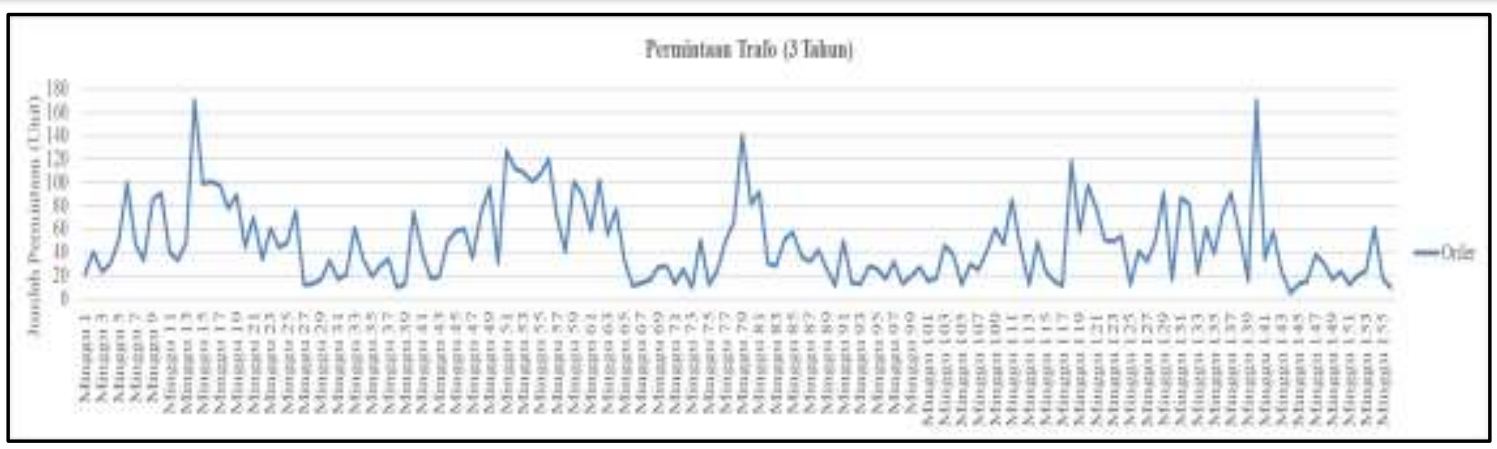

Gambar 1. Permintaan Trafo

Dengan pola permintaan diatas untuk memenuhi permintaan yang fluktuatif perlu memilih metode peramalan yang tepat dalam menentukan Stock Day On Hand (SDOH) yang digunakan untuk mengantisipasi permintaan yang masuk secara tiba-tiba, bisa dengan menggunakan metode SARIMA yang dimana diidentifikasi pada pola tersebut mengandung pola musiman, maka dari itu metode ini cocok dan dapat dijadikan pertimbangan untuk mengatasi permasalahan diatas dikarenakan kelebihan metode SARIMA sendiri yaitu dapat digunakan untuk peramalan dengan pola msuiman serta fluktuatif.

\section{A. Transformator}

Transformator merupakan salah satu alat listrik yang bisa digunakan dalam menghantarkan serta mengubah energy listrik dari satu rangkaian ke rangkaian lainnya. Transformator juga memiliki berbagai jenis yang beragam, akan tetapi secara umum dapat diklasifikasi menjadi tiga jenis yaitu transformator daya, transformator distribusi, dan transformator pengukuran[1].

\section{B. Uji Stasioner}

Data stasioner adalah data dimana rata-rata nilai pada suatu data tidak berubah seiring dengan perubahan waktu, dengan kata lain fluktuatif data berada di sekitar nilai rata-rata dan varian yang konstan[2]. Sedangkan uji stasioner adalah sebuah tahapan yang dianggap paling penting yang nantinya akan digunakan dalam analisa data time series yang bertujuan untuk menghilangkan otokorelasi yang dapat menyebabkan data yang kita olah menjadi tidak stasioner[3].

\section{Uji Stasioner Terhadap Varian}

Untuk mengetahui kestasioneran data dalam varian dapat digunakan metode korelaasi spearmean. Metode matematis aatau persamaan yang digunakan adalah[4]:

$\mathrm{rs}=1-6\left(\frac{\sum_{i=1}^{n} d i^{2}}{n\left(n^{2}-1\right)}\right)$

Setelah melakukn perhitungan menggunakan rumus diatas, dilakukan pengecekan nilai lamda. Nilai lamda sangat mempengaruhi persamaan transformasi untuk merubah data aktual menjadi data yang transformasi stasioner, dengan arti lain data dapat dikatakan stasioner apabila nilai lamda sudah mencapai nilai saatu. Adapun tabel transformasi berikut:

Tabel 1. Transformasi

\begin{tabular}{cc}
\hline$\Lambda$ & Transformasi \\
\hline 2 & $\mathrm{X}^{2}$ \\
\hline 0,5 & $\sqrt{\mathrm{X}}$ \\
\hline 0 & $\mathrm{In} \mathrm{X}$ \\
\hline$-0,5$ & $1 / \sqrt{\mathrm{X}}$ \\
\hline$-1,0$ & $1 / \mathrm{X}$ \\
\hline
\end{tabular}

\section{Uji Stasioner Terhadap Rata-Rata}

Setelah syarat stasioner dalam varian telah dipenuhi maka syarat kedua adalah stasione dalam maen. Untuk itu kita dapat menguji metode Dickey fuller. Berikut adalah model matematis dengan menggunakan augmented dickey fuller yaitu sebagai berikut: 
Procedia of Engineering and Life Science Vol. 1. No. 1 May 2021

Seminar Nasional \& Call Paper Fakultas Sains dan Teknologi (SENASAINS $2^{\text {nd }}$ )

Universitas Muhammadiyah Sidoarjo

$\Delta \mathrm{Y}_{\mathrm{t}}=\alpha+\delta \mathrm{t}+\rho \mathrm{Y}_{\mathrm{t}-1}+\sum_{j=1}^{k} \phi_{j} \Delta \mathrm{Y}_{\mathrm{t}-1}+e_{\mathrm{t}}$

\section{E. Seasonal ARIMA}

Seasonal ARIMA merupakan salah satu metode deret waktu yang terdiri dari pola musiman. Seasonal ARIMA sendiri dapat ditulis dalam bentuk $(\mathrm{p}, \mathrm{d}, \mathrm{q})(\mathrm{P}, \mathrm{D}, \mathrm{Q})^{\mathrm{S}}[5]$. Apabila dituliskan dalam persamaan dapat ditulis sebagai berikut:

$\varphi(\mathrm{B}) \Phi \mathrm{p}(\mathrm{Bs})(1-\mathrm{B}) \mathrm{d}(1-\mathrm{Bs}) \mathrm{DYt}=\theta \mathrm{q}(\mathrm{B}) \Theta \mathrm{Q}(\mathrm{Bs}) \mathrm{at}$

\section{F. Autocorrelation Function (ACF)}

Autocorrelation Function adalah ukuran ringkasan yang mengukur sejauh mana hubungan linier antara dua variabel. Secara matematis untuk menghitung autokorelasi dapat dihitung dengan persamaan autokorelasi pada lag $\mathrm{k}$ dengan rk. Kemudian tentukan:

$r \mathrm{k}=\frac{\sum_{\mathrm{t}=\mathrm{k}+1}^{\mathrm{n}}\left(\mathrm{Y}_{\mathrm{t}}-\overline{\mathrm{Y}}\right)\left(\mathrm{Y}_{\mathrm{t}-\mathrm{k}}-\overline{\mathrm{Y}}\right)}{\sum_{\mathrm{t}=\mathrm{k}+1}^{\mathrm{n}}\left(\mathrm{Y}_{\mathrm{t}}-\overline{\mathrm{Y}}\right)^{2}}$

\section{G. Partial Autocorrelation Function (PACF)}

Paartial Autocorrelation berfungsi sebagai korelasi diantra dua variabel setelah disesuaikan dengan faktor umum yang mungkin mempengaruhinya. Secara matematis persamaannya dapat ditulis sebagai berikut[4]:

$\phi_{\mathrm{k}+1, \mathrm{k}+1}=\frac{\rho_{k+1} \sum_{j=1}^{k} \phi_{k j} \rho_{k+1-j}}{1-\sum_{j=1}^{k} \phi_{k j} \rho_{j}}$
$\phi_{\mathrm{k}+1, \mathrm{j}}=\phi_{\mathrm{kj}}-\phi_{\mathrm{k}+1, \mathrm{k}+1} \phi_{\mathrm{k}, \mathrm{k}+1-\mathrm{j}}$

\section{H. Identifikasi Model}

Dalam menentukan model SARIMA yang nantinya akan digunakan dalam perhitungan SARIMA, terlebih dahulu untuk mengidentifikasi pola data plot ACF dan PACF. Dari plot ACF dan PACF tersebut dilihat pada lag awal serta lag yang mengandung musiman.

\section{White Noise}

Proses white noise adalah sebagai deret variabel acak yang independen, identik dan terdistribusi serta memenuhi asumsi stasioner.[6]. Data dapat mencapai asumsi stasioner apabila nilai p-value lebih dari alpha $(0,05)[7]$.

\section{J. Pemilihan Model Terbaik}

Untuk memodelkan suatu data pada tipe data runtun waktu, terdapat probabilitas terhadap beberapa model yang didapatkan, bahwa model tersebut selesai, ditandai dengan telah memenuhinya signifikansi terhadap parameter sebagai tolak ukur uu persyaratanya (residual sudah memenuhi asumsi baik white noise maupun yang berdistribusi normal). Hal ini dapat dilakukan pemilihan model terbaik, selain itu sebagai pertimbangan untuk kelayakan model yang terpilih dengan melakukan perhitungan nilai tingkat kesalahan yang terbagi menjadi dua yaitu Mean Square Error (MSE) dan Mean Absolute Percentage Error (MAPE).

\section{K. Mean Square Error (MSE)}

MSE (Mean Square Error) adalah suatu perhitungan yang digunakan untuk menghitung nilai rata-rata kesalahan yang dipangkatkan[8]. Secara matematis dapat ditulis sebagai berikut:

$\mathrm{MSE}=\frac{\sum \text { error }^{2}}{n}$

\section{Mean Absolute Percentage Error (MAPE)}

MAPE dikatakan bahwa persentase dari selisih hasil peramalan dengan data aktual yang nantinya memberikan sebuah informasi apakah kesalahan tersebut tergolong tinggi atau rendah selama rentan waktu yang ditentukan. Persamaannya yaitu:

$$
\text { MAPE }=\left(\frac{100}{n}\right) \sum\left|A_{t}-\frac{F_{t}}{A_{t}}\right|
$$

Apabila hasil dari MAPE kurang dari 10\% maka hasil peramalan dikatakan sangat baik, apabila $10 \%$ hingga $20 \%$ maka hasil peramalan dikatakan baik, apabila hasilnya $20 \%$ hingga 50\% hasil peramalan dapat dikatakan cukup baik dan apabila hasil lebih dari 50\% maka hasil peramalan dikatakan buruk[9].

\section{Safety Stock}

Safety stock atau stok pengaman merupakan banyaknya rata-rata persediaan yang dimiliki untuk kemungkinan ketidakpastian permintaan dan ketidakpastian penawaran dalam jangka pendek atau bisa juga diartikan sebagai persediaan tambahan yang digunakan untuk mengantisipasi terjadinya kekurangan bahan[10]. 
Procedia of Engineering and Life Science Vol. 1. No. 1 May 2021

Seminar Nasional \& Call Paper Fakultas Sains dan Teknologi (SENASAINS 2nd)

Universitas Muhammadiyah Sidoarjo

\section{METODE}

Data yang diambil dalam penelitian ini adalah data yang didapat dari observasi lapangan serta hasil wawancara karyawan yang terkait sehingga didapatkan berupa data permintaan produksi yang memiliki pola data fluktuatif serta data persediaan bahan baku yang digunakan untuk melakukan peramalan produksi dimasa mendatang serta menentukan stock day on hand. Data yang digunakan dalam pengolahan nantinya yaitu diambil empat tahun terakhir yang dimulai dari tahun 2017 hingga tahun 2020.

\section{HaSil Dan PeMbahasan}

\section{A. Pengujian Stasioner Data}

Pengujian yang dilakukan memiliki tujuan untuk mengetahui data yang digunakan tidak memiliki kesenjangan data yang signifikan. Dalam pengujian stasioner data dibagi menjadi dua yaitu uji stasioner data terhadap varian serta uji stasioner data terhadap rata-rata. Berikut adalah hasil dari proses uji stasioner terhadap varian.

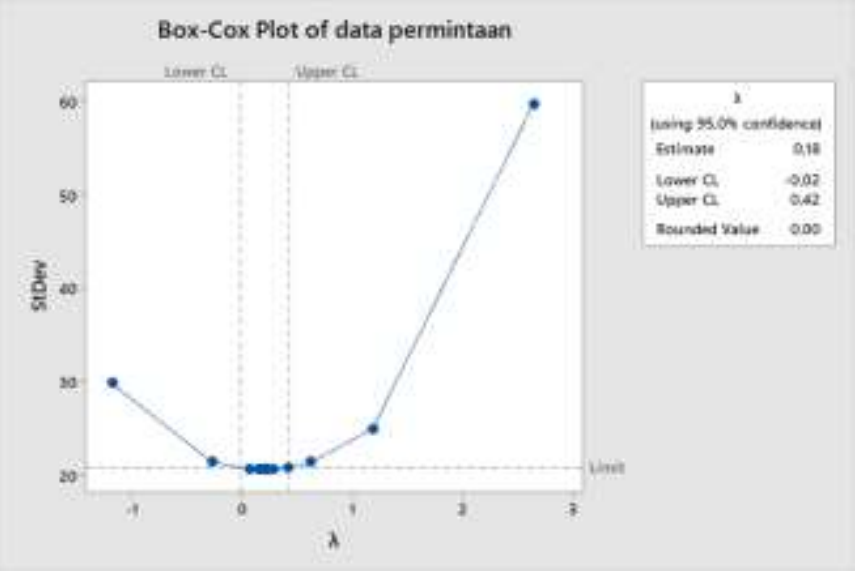

Gambar 1. Uji Stasioner Data Trafo Belum Stasioner

Hasil pengujian stasioner terhadap varian pada gambar 1 didapatkan hasil rounded value belum bernilai 1 yang menandakan data tersebut belum stasioner. Maka untuk menstasionerkan data tersebut, bisa dengan cara transformasi data. Maka hasil yang didapat sebagai berikut:

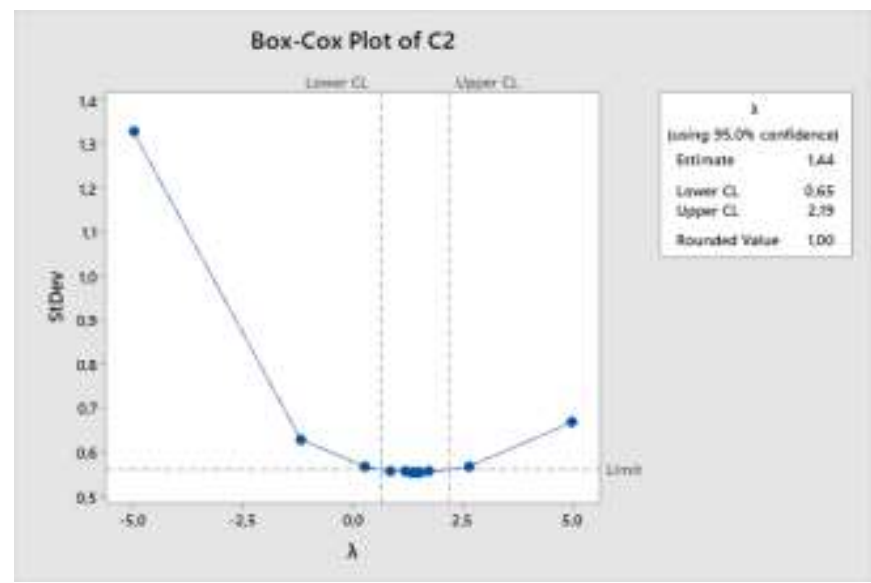

Gambar 2. Uji Stasioner Data Trafo Sudah Stasioner

Setelah mendapatkan hasil data yang sudah stasioner terhadap varian, selanjutnya dilakukan pengujian stasioner data terhadap rata-rata, pengujian tersebut dilakukan dengan uji unit root augmented dickey fuller yang menghasilkan pada tabel 1 berikut: 
Procedia of Engineering and Life Science Vol. 1. No. 1 May 2021

Seminar Nasional \& Call Paper Fakultas Sains dan Teknologi (SENASAINS 2nd)

Universitas Muhammadiyah Sidoarjo

Tabel 1. Pengujian Augmented Dickey Fuller

Null Hypothesis: TRANSFORMASI1 has a unit root

Exogenous: Constant

Lag Length: 1 (Automatic - based on SIC, maxlag=13)

\begin{tabular}{lccc}
\hline \hline & & & \\
& & & \\
& & & \\
Augmented Dickey-Fuller & & Prob. $^{*}$ \\
\hline Test critical valistic & 1\% level & -5.426583 & 0.0000 \\
\hline & 5\% level & -3.473096 & \\
& 10\% level & -2.880211 & \\
\hline \hline
\end{tabular}

*MacKinnon (1996) one-sided p-values.

Dari hasil uji root augmented dickey fuller mendapati hasil probabilitas 0,0000 yang dimana kurang dari 0,05 yang dimana bisa disimpulkan bahwa data dapat dikatakan sudah stasioner terhadap rata-rata. Setelah melewati dua pengujian stasioner data dan data sudah stasioner terhadap varian maupun rata-rata, selanjutnya dilakukan plotting autokorelasi serta parsial autokorelasi. Untuk plotting autokorelasi dan parsial autokorelasi dapat dilihat pada gambar 3.
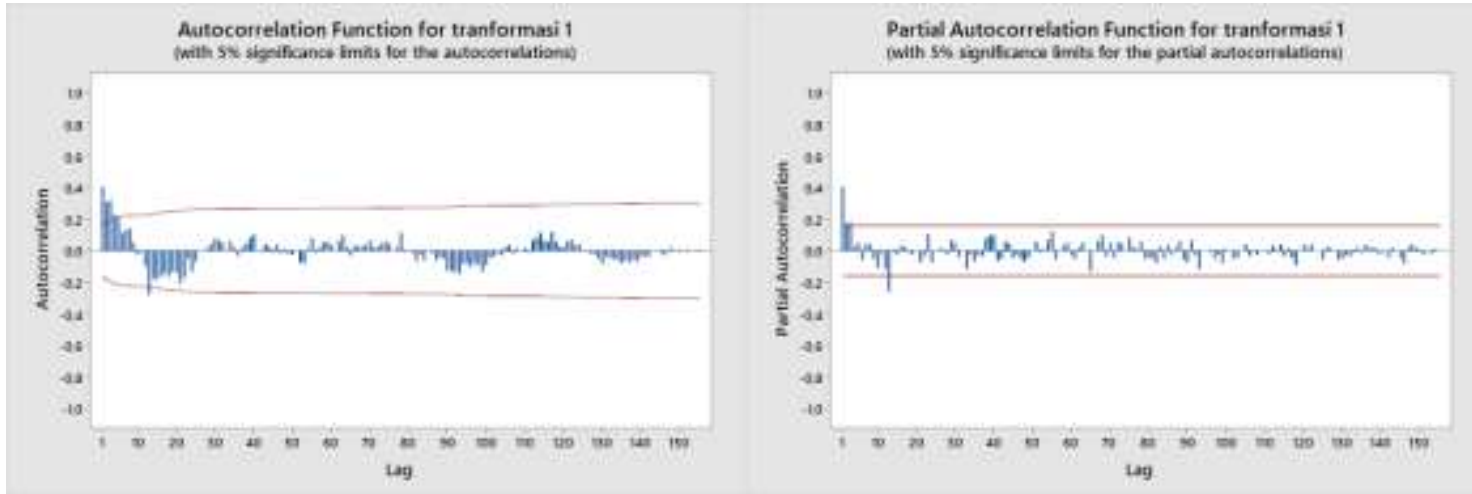

Gambar 3. Plotting Autokorelasi \& Parsial Autokorelasi Data Transformasi

Dari hasil plotting diatas, dilakukan analisa grafik yang dimana dari kedua hasil plotting diduga terdapat faktor musiman pada lag ke 13, maka perlu dilakukan differencing pada lag ke 13. Setelah dilakukan differencing, maka membuat plotting autokorelasi dan parsial autokorelasi dengan disertai faktor musiman, bisa dilihat pada gambar 4.
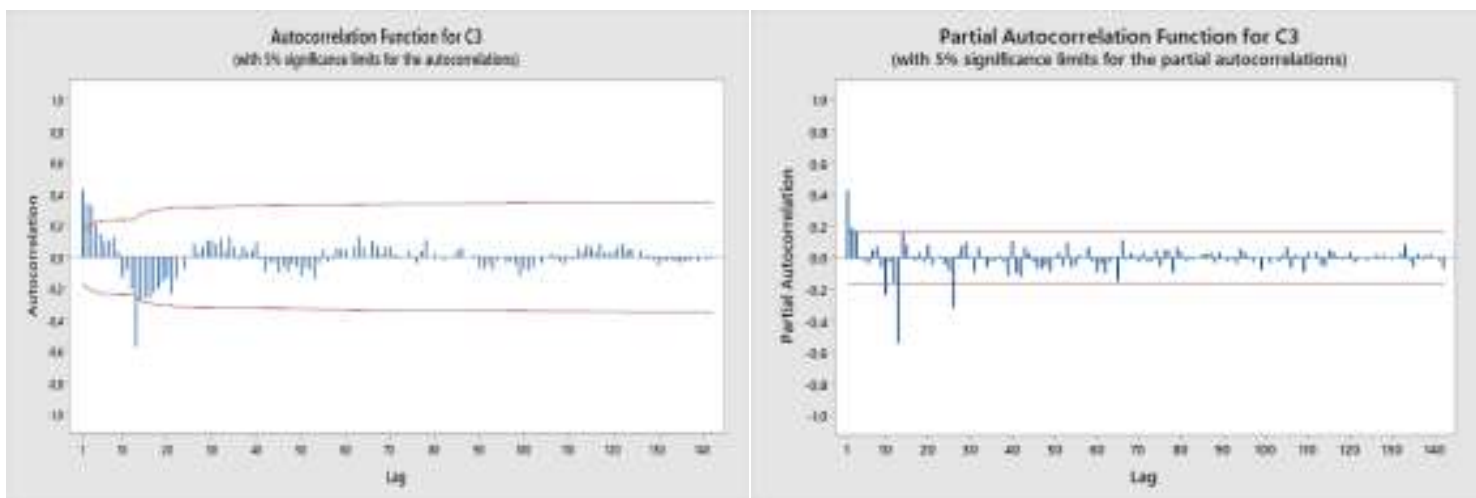

Gambar 4. Plotting Autokorelasi \& Parsial Autokorelasi Data Transformasi Musiman

Setelah kita melakukan pengujian data melalui uji stasioner terhadap rata-rata dan varian, lalu bisa dilakukan tahapan selanjutnya yaitu pengujian parameter. Sebelumnya dilakukan identifikasi terhadap model yang didapat dari pendugaan-pendugaan dari grafik diatas. Hasil identifikasi model didapat model SARIMA $(1,0,0)(1,1,0)^{13}$ dengan alternatif model yaitu model SARIMA $(1,0,2)(1,1,1)^{13}$, model SARIMA $(1,0,1)(1,1,1)^{13}$, dan masih banyak alternatif yang bisa diidapatkan. Maka langkah berikutnya yaitu pengujian parameter yang sudah diperoleh dan dicari hasil yang terbaik. 
Procedia of Engineering and Life Science Vol. 1. No. 1 May 2021

Seminar Nasional \& Call Paper Fakultas Sains dan Teknologi (SENASAINS 2nd)

Universitas Muhammadiyah Sidoarjo

Dari banyaknya model terdapat dua model yang semua parameternya memenuhi asumsi signifikansi yaitu model SARIMA $(1,0,2)(1,1,1)$ dan model SARIMA $(1,0,1)(1,1,1)$. Dikarenakan terdapat lebih dari dua model yang memenuhi asumsi signifikansi maka dilakukan pengujian residual white noise.

\section{B. Uji White Noise}

Melakukan pengujian white noise dengan menggunakan statistik uji Ljung-Box pada model yang memenuhi uji parameter signifikasi. Pada kedua model tersebut dilakukan hipotesis white noise dengan kriteria diteriima $\mathrm{H}_{0}$ apabila P-Value $>\alpha(0.05)$ atau uji statistic $\mathrm{Q}<\mathrm{X} 2$ tabel. Hasil uji parameter signifikasi model pertama yaiut sebagai berikut:

Tabel 2. Hasil Uji Parameter Model SARIMA $(1,0,2)(1,1,1)$

\begin{tabular}{cccc}
\hline Lag & Chi-Square & $D F$ & P-Value \\
\hline 12 & 25,80 & 6 & 0,000 \\
\hline 24 & 47,60 & 18 & 0,000 \\
\hline 36 & 61,51 & 30 & 0,000 \\
\hline 48 & 64,94 & 42 & 0,013 \\
\hline
\end{tabular}

Tabel 3. Hasil Uji Parameter Model SARIMA $(1,0,1)(1,1,1)$

\begin{tabular}{cccc}
\hline Lag & Chi-Square & DF & P-Value \\
\hline 12 & 2,96 & 7 & 0,889 \\
\hline 24 & 10,89 & 19 & 0,928 \\
\hline 36 & 21,86 & 31 & 0,887 \\
\hline 48 & 26,24 & 43 & 0,979
\end{tabular}

Dari 2 model tersebut dapat diketahui jika model yang memenuhi asumsi White Noise yaitu Model SARIMA $(1,0,1)(1,1,1) 13$ dan terdapat model yang ditolak yaitu Model SARIMA $(1,0,2)(1,1,1) 13$. Setelah mendapatkan 1 model yang memenuhi syarat maka tahap selanjutnya yaitu proses perhitungan nilai MSE dan MAPE pada model yang dipilih sebelum digunakan untuk peramalan.

\section{Peramalan Trafo}

Untuk meramalkan jumlah produksi trafo dimasa mendatang dengan menggunakan metode SARIMA dengan model SARIMA $(1,0,1)(1,1,1)^{13}$ yang menghasilkan persamaan secara sistematis dapat ditulis sebagai berikut:

$$
Z_{\mathrm{t}}=-\phi_{1} \phi_{2} \mathrm{Z}_{\mathrm{t}-14}+\phi_{1} \phi_{2} \mathrm{Z}_{\mathrm{t}-27}+\Theta_{1} \Theta_{2} €_{\mathrm{t}-14}+€_{\mathrm{t}}
$$

Dari persamaan rumus model SARIMA tersebut akan menghasilkan peramalan dimasa mendatang atau meramalkan 14 minggu kedepan. Hasil peramalan dapat dilihat pada tabel 4 sebagai berikut:

Tabel 4. Hasil Peramalan Produksi Trafo

\begin{tabular}{cccc}
\hline Periode & $\begin{array}{c}\text { Ramalan } \\
\text { Produksi 2021 }\end{array}$ & $\begin{array}{c}\text { Produksi Aktual } \\
\text { Tahun 2020 }\end{array}$ & $\begin{array}{c}\text { GAP Peramalan } \\
\text { \& Aktual }\end{array}$ \\
\hline 1 & 48 & 34 & $(14)$ \\
\hline 2 & 69 & 35 & $(34)$ \\
\hline 3 & 15 & 25 & 10 \\
\hline 4 & 18 & 18 & 0 \\
\hline 5 & 61 & 35 & 7 \\
\hline 6 & 20 & 28 & 31 \\
\hline 7 & 2 & 33 & $(82)$ \\
\hline 8 & 110 & 29 & $(49)$ \\
\hline 9 & 99 & 50 & 8 \\
\hline 10 & 36 & 44 & $(65)$ \\
\hline 11 & 8 & 29 & $(45)$ \\
\hline 12 & 148 & 83 & $(66)$ \\
\hline 13 & 107 & 62 & 70 \\
\hline 14 & 135 & 70 & \\
\hline
\end{tabular}

Dari tabel diatas dapat dilihat bahwa hasil antara ramalan dengan produksi aktual dapat dikatakan cukup mendekati namun keduanya memiliki range yang berbeda. Terlihat pada tabel 4.14 hasil dari peramalan cenderung menurun. Hal tersebut dikarenakan pola data out sample yang digunakan untuk peramalan memiliki trend menurun sehingga hasil ramalan juga menurun untuk trend nya, bukan berarti menurun secara beruntun. Terlihat pada gambar 5 . 
Procedia of Engineering and Life Science Vol. 1. No. 1 May 2021

Seminar Nasional \& Call Paper Fakultas Sains dan Teknologi (SENASAINS 2nd)

Universitas Muhammadiyah Sidoarjo

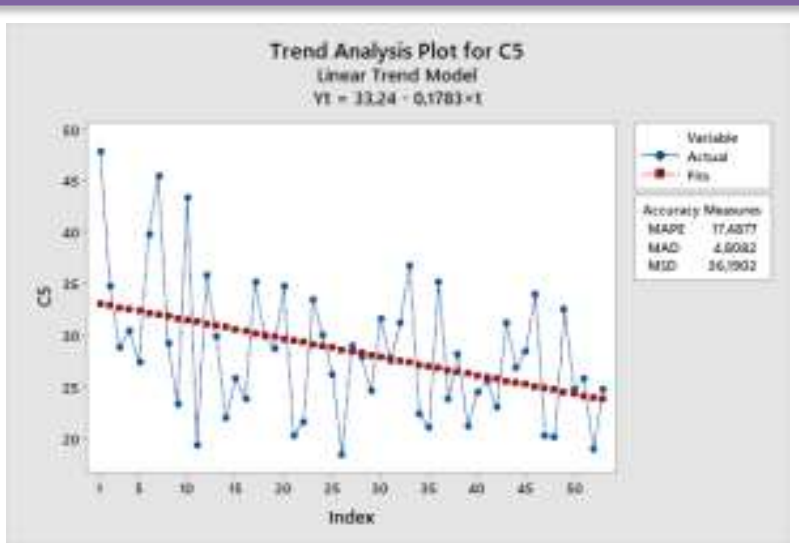

Gambar 5. Grafik Trend Permintaan Aktual Trafo

\section{Penentuan Safety Stock}

Sebelum melakukan perhitungan safety stock harus mengetahui bahan material apa yang ingin di ramalkan untuk memenuhi permintaan yang ada. Persediiaan material bisa dilihat pada tabel 5 .

Tabel 5. Persediaan Material LV Busing

\begin{tabular}{cccccccccccccccccc}
\hline $\begin{array}{c}\text { Material } \\
\text { for }\end{array}$ & Usage & U.M & $\begin{array}{c}\text { Des } \\
19\end{array}$ & $\begin{array}{c}\text { Jan- } \\
20\end{array}$ & Feb & Mar & Apr & Mei & Jun & Jul & Ags & Sept & Okt & Nov & Des \\
\hline $\begin{array}{c}\text { LV } \\
\text { Busing }\end{array}$ & 4 & Pcs & 1978 & 844 & 994 & 1094 & 625 & 929 & 807 & 205 & 1172 & 358 & 1140 & 864 & 1142 \\
\hline
\end{tabular}

Kemudian apabila data persediaan material sudah didapatkan, langkah selanjutnya yaitu melakukan perhitungan safety stock. Sebelumnya data yang saya ramalkan dalam bentuk mingguan, yang saya lakukan yaitu akan saya ubah jadi bulanan. Maka untuk perhitungannya bisa dilihat pada tabel 6.

Tabel 6. Produksi Aktual Tahun 2020 Safety Stock

\begin{tabular}{|c|c|c|c|c|c|c|c|}
\hline \multirow{3}{*}{ Bulan } & \multirow{2}{*}{$\begin{array}{c}\text { Produksi } \\
\text { Aktual } \\
2020\end{array}$} & \multicolumn{6}{|c|}{ Material LV Busing (pcs) } \\
\hline & & $\begin{array}{c}\text { Jumlah } \\
\text { Kebutuhan } \\
\text { Unit (pcs) }\end{array}$ & $\begin{array}{c}\text { Jumlah } \\
\text { Kebutuhan } \\
\text { Aktual }\end{array}$ & $\begin{array}{l}\text { Persediaan } \\
\text { Material } \\
\text { (pcs) }\end{array}$ & $\begin{array}{c}\text { Sisa } \\
\text { Material } \\
(\mathrm{pcs})\end{array}$ & $\begin{array}{c}\text { Order } \\
\text { Arrival (pcs) }\end{array}$ & $\begin{array}{r}\text { Stock Day } \\
\text { On Hand }\end{array}$ \\
\hline & (A) & (B) & $(\mathrm{C}=$ At $\times \mathrm{B})$ & (D) & $(\mathrm{E}=\mathrm{Dt}-\mathrm{Ct})$ & $(\mathrm{F}=\mathrm{Dt}-\mathrm{Et})$ & $(\mathrm{G}=\mathrm{Dt}-\mathrm{It})$ \\
\hline Des 2019 & & & & 1978 & & & \\
\hline Januari & 287 & 4 & 1148 & 844 & 830 & 14 & 30 \\
\hline Februari & 248 & 4 & 992 & 994 & -148 & 1142 & 36 \\
\hline Maret & 197 & 4 & 788 & 1094 & 206 & 888 & 39 \\
\hline April & 324 & 4 & 1296 & 625 & -202 & 827 & 22 \\
\hline Mei & 157 & 4 & 628 & 929 & -3 & 932 & 33 \\
\hline Juni & 300 & 4 & 1200 & 807 & -271 & 1078 & 29 \\
\hline Juli & 182 & 4 & 728 & 205 & 79 & 126 & 7 \\
\hline Agustus & 193 & 4 & 772 & 1172 & -567 & 1739 & 42 \\
\hline September & 130 & 4 & 520 & 358 & 652 & - & 13 \\
\hline Oktober & 112 & 4 & 448 & 1140 & -90 & 1230 & 41 \\
\hline November & 140 & 4 & 560 & 864 & 580 & 284 & 31 \\
\hline Desember & 288 & 4 & 1152 & 1142 & -288 & 1430 & 41 \\
\hline Total & & & 10232 & & & & \\
\hline Rata - Rata & & & 853 & & & & \\
\hline
\end{tabular}


Procedia of Engineering and Life Science Vol. 1. No. 1 May 2021

Seminar Nasional \& Call Paper Fakultas Sains dan Teknologi (SENASAINS 2nd)

Universitas Muhammadiyah Sidoarjo

Setelah mendapatkan perhitungan produksi aktual material LV Busing, maka hasil tersebut digunakan untuk perencanaan kebutuhan material untuk produksi ditahun mendatang dan perhitungannya dapat dilihat pada tabel 8 .

Tabel 8. Perencanaan Safety Stock Tahun 2021

\begin{tabular}{|c|c|c|c|c|c|c|}
\hline \multirow{3}{*}{ Bulan } & & \multicolumn{5}{|c|}{ Material LV Busing (pcs) } \\
\hline & $\begin{array}{c}\text { Perencanaan } \\
\text { Produksi } \\
\text { Tahun } 2021\end{array}$ & $\begin{array}{l}\text { Jumlah } \\
\text { Kebutuhan } \\
\text { Unit (pcs) }\end{array}$ & $\begin{array}{c}\text { Jumlah } \\
\text { Kebutuhan } \\
\text { Aktual } \\
\text { Tahun } 2020\end{array}$ & $\begin{array}{l}\text { Perencanaan } \\
\text { Jumlah Order } \\
\text { Kebutuhan } \\
\text { Tahun } 2021 \\
\text { (pcs) }\end{array}$ & $\begin{array}{c}\text { Stock Plan } \\
\text { Tahun } 2021 \\
\text { (pcs) }\end{array}$ & $\begin{array}{l}\text { Stock Day } \\
\text { On Hand } \\
\text { (hari) }\end{array}$ \\
\hline & (D) & (E) & ( C ) & $(\mathrm{F}=\mathrm{D} * \mathrm{E})$ & $(\mathrm{G}=\mathrm{Gi}-\mathrm{C}+\mathrm{F})$ & $(\mathrm{H}=\mathrm{Gi} / \mathrm{I})$ \\
\hline $\begin{array}{c}\text { Desember } \\
2020\end{array}$ & & & & & 1142 & \\
\hline Januari & 211 & 4 & 1148 & 844 & 838 & 30 \\
\hline Februari & 232 & 4 & 992 & 928 & 774 & 28 \\
\hline Maret & 434 & 4 & 788 & 1736 & 1722 & 62 \\
\hline
\end{tabular}

Dari perhitungan tabel diatas mengartikan bahwa persediaan pada bulan januari dapat digunakan untuk 30 hari kedepan atau pada bulan februari. Untuk perencanaan produksi 1 bulan yaitu 30 hari, dengan persediaan yang akan habis dalam waktu 30 hari maka dapat dipastikan pihak perusahaan tidak akan mengalami kelebihan dan kekurangan material dan juga sebaliknya (tergantung pada stock day on hand) pada bulan berikutnya.

\section{KeSIMPULAN}

Dari hasil penelitian dan analisa secara umum dapat disimpulkan sebagai berikut : (1) Model terbaik yang dapat digunakan untuk meramalkan produksi trafo pada periode yang akan dating pada PT. XYZ adalah model SARIMA $(1,0,1)(1,1,1)$ dengan persamaan $\mathrm{Z}_{\mathrm{t}}=-\phi_{1} \phi_{2} \mathrm{Z}_{\mathrm{t}-14}+\phi_{1} \phi_{2} \mathrm{Z}_{\mathrm{t}-27}+\Theta_{1} \Theta_{2} €_{\mathrm{t}-14}+€_{\mathrm{t}}$. (2) Untuk mengantisipasi kelebihan dan kekurangan material yang nanti berimbas pada biaya simpan pada gudang ataupun keterlambatan (bottleneck) kegiatan produksi kedepannya, maka pada stock plan dapat dikurangi ataupun ditambah sesuai dengan kebijakan perusahaan untuk mencapat stock day on hand yang telah ditetapkan oleh perusahaan yaitu sebesar 30 sampai 35 hari. (3) Dari model peramalan SARIMA didapatkan nilai MSE serta MAPE dari perhitungan menggunakan model SARIMA $(1,0,1)(1,1,1$,$) dengan menghasilkan nilai MSE dan MAPE optimal untuk MSE sebesar 797,94 dengan nilai$ MAPE sebesar 37,87\% yang dimana dari hasil perhitungan MAPE, maka dapat dianalisa dengan hasil MAPE sebesar $37,87 \%$ hasil peramalan yang dihasilkan dengan menggunakan

\section{UCAPAN TERIMA KASIH}

Saya sebagai penulis sekalian peneliti mengucapkan terima kasih untuk Universitas Muhammadiyah Sidoarjo yang telah memberikan saya kesempatan untuk mengajukan penelitian ini hingga saya dapat menyelesaikannya. Tidak lupa juga saya mengucapkan terima kasih kepada keluarga dan teman-teman yang telah berkontribusi memberikan doa, semangat atau motivasi sehingga saya dapat menyelesaikan penelitian ini dengan baik dan lancar. Semoga dari penelitian ini dapat menambah wawasan bagi pembaca.

\section{REFERENSI}

[1] Sogen, Markus Dwiyanto Tobi., “Analisis Pengaruh Ketidakseimbangan Beban Terhadap Arus Netral dan Losses Pada Transformator Distribusi Di PT. PLN (Persero) Area Sorong” Jurnal Electro Luceat, vol. 4, no. 1, pp. 110, 2018.

[2] Prahesti, Danica Dwi, Entit Puspita, Fitriani Agustina, "Peramalan Curah Hujan Kota Bandung Menggunakan Model FUngsi Transfer Multivariat Pada Deret Berkala Musiman” Eureka Matika, vol. 4, no. 1, pp. 104-118, 2016.

[3] Sari, Ratih Kumala, “Analisis Impor Beras di Indonesia” Economics Development Analysis Journal., vol. 3, no. 2, pp. 320-325, 2014.

[4] Rahmadayanti, Riza, Boko Susilo, Diyah Puspitaningrum, "Perbandingan Keakuratan Metode Autoregressive Integrated Moving Average (ARIMA) dan Exponential Smoothng Pada Peramalan Penjualan Semen di PT. Sinar Abadi” Jurnal Rekursif, vol. 3, no. 1, pp. 23-36, 2015.

[5] Rahmalina, Widdya, Novreta, "Peramalan Indeks Kekeringan Kelayang Menggunakan Metode SARIMA dan 
Procedia of Engineering and Life Science Vol. 1. No. 1 May 2021

Seminar Nasional \& Call Paper Fakultas Sains dan Teknologi (SENASAINS 2nd)

Universitas Muhammadiyah Sidoarjo

SPI” Potensi, vol. 22, no. 1, pp. 64-75, 2020.

[6] Tantika, Hani Nastiti, Nanang Supriadi, Dian Anggraini, "Metode Seasonal ARIMA Untuk Meramalkan Produksi Kopi Dengan Indikator Curah Hujan Menggunakan Aplikasi R di Kabupaten Lampung Barat" Jurnal Matematika, vol. 17, no. 2, pp 49-58, 2018.

[7] Pamungkas, Muhammad Bintang, Arief Wibowo, “Aplikasi Metode ARIMA Box-Jenkins Untuk Meramalkan Kasus DBD di Provinsi Jawa Timur,” The Indonesian Journal Public Health., vol. 13, no. 2, pp. 181-194, 2018.

[8] Maricar, M. Azman, "Analisa Perbandingan Nilai Akurasi Moving Average dan Exponential Smoothing Untuk Sistem Peramalan Pendapatan Pada Perusahaan XYZ” Jurnal Sistem dan Informatika., vol. 13, no. 2, pp. 36-45, 2015.

[9] Masrudin, Neva Satyahadewi, Nurfitri Imro'ah, "Peramalan Jumlah Wisatawan Mancanegara di Kota Pontianak Dengan Metode Deseasonalized” Bimaster, vol. 7, no. 3, pp. 159-168, 2018.

[10] Chusminah SM, R. Ati Haryati, Fera Nelfianti, "Efektifitas Pengelolaan Persediaan Barang Dengan Sistem Safety Stock Pada PT. X di Jakarta” Journal Economic Resources., vol. 2, no. 1, pp. 1-13, 2019. 